\title{
Konflik peran pada jero yang menjalani prosesi ngerawang Di kabupaten Bangli
}

\author{
Ni Luh Mas Ristha Cempaka dan David Hizkia Tobing \\ Program Studi Psikologi, Fakultas Kedokteran, Universitas Udayana \\ davidhizkia@yahoo.com
}

\begin{abstract}
Abstrak
Bali sangat terkenal dengan kebudayaan dan upacara-upacara adat yang hingga saat ini masih dilestarikan. Salah satu upacara adat yaitu ngerawang merupakan upacara agama yang hingga saat ini masih dilaksanakan oleh masyarakat salah satu desa di Kabupaten Bangli. Individu yang telah melaksanakan upacara ngerawang memiliki sebutan sebagai seorang jero dan harus melaksanakan tugas dan kewajiban sebagai pemimpin upacara. Seorang jero juga memiliki peran-peran lain yang bertujuan untuk memenuhi kebutuhan sehari-hari, namun peran sebagai seorang jero tidak boleh ditinggalkan begitu saja. Individu yang tidak dapat menjalankan peran-peran yang dimiliki dengan baik, dapat menimbulkan permasalahan yang memicu timbulnya konflik antar peran. Berdasarkan hal tersebut, peneliti ingin mengetahui konflik peran pada jero yang menjalani prosesi ngerawang kabupaten Bangli.

Penelitian ini menggunakan metode penelitian kualitatif dengan pendekatan studi kasus. Jumlah responden pada penelitian ini adalah dua orang. Responden pertama berjenis kelamin laki-laki, berusia 35 tahun dengan pekerjaan utama sebagai seorang guru dan responden kedua berjenis kelamin perempuan berusia 24 tahun yang bekerja sebagai bidan. Kedua responden penelitian ini menjalankan prosesi ngerawang dan memiliki peran sebagai jero. Penelitian ini menghasilkan dua tema temuan, yaitu tema pertama adalah pengalaman awal responden sebelum melaksanakan prosesi ngerawang dan tema kedua adalah konflik peran yang merupakan temuan utama dalam penelitian ini.
\end{abstract}

Kata kunci: Jero, konflik, konflik peran, ngerawang

\begin{abstract}
Bali is very famous for it is culture and traditional ceremonies which up until now still preserved. One of Balinese traditional ceremony that is ngerawang. Ngerawang is religious ceremony which till now still being held by the society on of the village in Bangli Regency. Individuals who has done ngerawang ceremony have a title as jero and must carry out the duties and obligations of the ceremonial leader. Jero also has other roles which intend to fulfill daily needs, yet the roles as jero should not be abandoned. Individuals who can't carry out the duties nicely, may cause problem that trigger conflict between roles. According to that, the researcher wants to analyze the role conflict of jero who undergo the procession of ngerawang in Bangli Regency.

This study uses qualitative research methods by using case study approach. The amount of the respondents in this research is two person. First respondent is male 35 years old his main job is as a teacher and the second respondent is female 24 years old who work as a midwife. Both respondents in this research has undergo ngerawang ceremony and have a role as jero. This research resulting two theme findings. That is the first time is initial experienceof the respondent before doing the ngerawang ceremony and second theme is the role conflict which is the main thing in this research.
\end{abstract}

Keywords: Conflict, jero, ngerawang, role conflict 


\section{N.L.M.R CEMPAKA DAN D.H TOBING}

\section{LATAR BELAKANG}

Indonesia merupakan salah satu negara dengan penduduk terpadat di dunia. Komposisi etnis di Indonesia sangat bervariasi karena negeri ini memiliki beragam suku dan budaya. Mulai dari upacara adat, busana adat dan bahasa yang berbeda disetiap daerah menjadi sebuah keunikan yang menjadi daya tarik tersendiri. Salah satu provinsi di Indonesia yang masih kental akan seni, budaya dan pelaksanaan upacara adat adalah Provinsi Bali. Ardana, Soenaryo, Sulandjari, Suwitha dan Putra (2011), menyebutkan bahwa kesenian yang dimiliki oleh masyarakat Bali membuat orang-orang tertarik untuk mengunjungi Pulau Bali. Wisatawan yang datang tidak hanya sekedar untuk berkunjung, namun juga tidak sedikit wisatawan yang tertarik untuk ikut langsung mengikuti rangkaian upacara adat, bahkan hingga menetap di Bali.

Terdapat salah satu desa di Bali yang hingga saat ini masih mempertahankan kegiatan adat istiadatnya, desa ini merupakan desa yang berada di Kecamatan Kintamani Kabupaten Bangli. Desa yang terletak di dataran tinggi dan di pesisir danau Batur membuat sebagian besar penduduk desa tersebut bekerja sebagai nelayan dan juga petani. Sama seperti desa-desa yang ada di Indonesia, desa yang terletak di Kabupaten Bangli ini juga memiliki budaya dan kebiasaan-kebiasaan serta kegiatan upacara agama yang hingga saat ini masih dipertahankan. Salah satu upacara agama yang masih saat ini dilaksanakan adalah upacara ngerawang.

Ngerawang merupakan istilah adat yang digunakan oleh masyarakat desa tersebut yang memiliki persamaan arti dan nilai dengan upacara pawintenan atau eka jati. Upacara pawintenan adalah salah satu upacara penyucian diri yang dilakukan oleh individu untuk menjadikan dirinya sebagai orang suci dengan sebutan jero. Pawintenan secara harafiah diartikan sebagai upacara untuk penyucian diri dan ada pula yang menyebutkan bahwa pawintenan berasal dari akar kata inten yang berarti permata yang sangat indah sehingga menarik dan menyejukkan hati setiap orang yang melihat (Swastika \& Pasek, 2009). Ngerawang merupakan tradisi unik yang hanya ada di salah satu desa di Kabupaten Bangli. Tradisi tersebut menaruh kepercayaan bahwa apabila individu mengalami permasalahan dalam hidupnya, salah satu solusi yang bisa dilakukan adalah melaksanakan upacara ngerawang. Bentukbentuk permasalahan seperti penyakit yang tidak kunjung sembuh, kesialan, kecelakaan dan sebagainya. Singkatnya, upacara ngerawang merupakan salah satu solusi efektif dari permasalahan yang dimiliki oleh masyarakat salah satu desa yang berada di Kabupaten Bangli.

Upacara ngerawang biasanya dilakukan di pura atau tempat suci lainnya seperti kamar suci dan ruangan khusus yang dibuat oleh keluarga calon jero untuk pelaksanaan prosesi upacara ngerawang. Kegiatan awal yang dilakukan adalah mengumpulkan beberapa masyarakat desa atau keluarga besar sebagai saksi dalam pelaksanaan upacara ngerawang, selanjutnya pelaksanaan upacara ngerawang dilanjutkan dengan pemanggilan "roh" para leluhur untuk mengesahkan upacara ngerawang tersebut dan individu yang telah ditunjuk sebelumnya telah sah menjadi seorang jero dan dapat menjalankan tugas dan kewajiban seorang jero (Cempaka, 2017).

Di desa tersebut ketika individu melaksanakan upacara ngerawang dengan cara individual atau masal, masyarakat lainnya akan memanggil individu tersebut dengan sebutan "jero" atau "jero mangku". Individu yang sudah melaksanakan upacara ngerawang atau pawintenan secara otomatis akan memiliki peran tambahan yaitu peran sebagai seorang jero. Dapat dikatakan bahwa ketika individu melaksanakan prosesi upacara ngerawang, maka individu tersebut harus sudah siap dengan status dan kehidupan barunya. Perannya dalam suatu prosesi upacara yadnya, maupun dalam tugas-tugas lainnya seorang jero dipandang menempati kedudukan yang penting dan terhormat dalam pandangan agama Hindu (Sudharta, dkk.,1991).

Sebutan jero di Bali pada umunya ada dua fungsi, yang pertama adalah peran jero pada wanita yang menikah dengan laki-laki berkasta lebih tinggi. Contohnya pada perempuan berkasta sudhra menikah dengan laki-laki berkasta triwangsa. Menurut Kerepu (dalam Vratasti \& Wilani, 2016) perempuan Bali dari wangsa sudhra yang menikah dengan laki-laki triwangsa (brahmana, ksatrya, dan waisya) namanya akan diganti dengan sebutan jero, diikuti dengan nama bunga seperti, cempaka, sandat, puspa, dll. Kedua adalah peran jero yang dapat berjenis kelamin laki-laki atau perempuan yang disucikan dengan upacara keagamaan dan bertugas sebagai pelaksana atau pemimpin upacara.

Menurut Sudharta, dkk., (1991) Secara umum tugas dan kewajiban jero atau pemangku adalah mengantarkan yadnya pada batas kewenangan yang telah di tetapkan, seperti memimpin upacara di pura, mengatur persembahyangan, melayani masyarakat atau umat yang ingin sembahyang ke pura baik siang maupun malam hari, hal yang sama berlaku bagi peran jero di salah satu desa yang terletak di Kabupaten Bangli. Kewajiban individu berstatus jero menurut Sudharta, dkk., (1991) pada saat melakukan tugasnya harus mengenakan pakaian serba putih, dandanan rambut harus rapi, harus memakai kain putih, baju putih, kampuh/saput atau selendang berwarna putih. Mengkonsumsi daging sapi atau babi merupakan sebuah pantangan bagi seorang jero, tidak boleh menggunakan barang-barang pribadi bersamaan dengan orang lain seperti handuk, piring dan gelas. Hal tersebut merupakan salah satu aturan yang harus dipatuhi oleh seorang jero (Swadiana, 2009).

Faktor pemilihan individu menjadi seorang jero sangatlah beragam. Menurut Sudharta, dkk., (1991) terdapat empat faktor pemilihan jero. Faktor pertama ditetapkan berdasarkan garis keturunan yaitu bilamana jero sebelumnya telah meninggal atau tidak dapat melaksanakan tugasnya lagi karena sakit atau sebab lainnya. Faktor kedua melalui pemilihan yaitu memilih seorang jero berdasarkan kesepakatan bersama dari para tokoh masyarakat atau tokoh agama. Faktor ketiga dengan cara nyanjan atau matuun yaitu pelaksanaan yang dilakukan di pura bertujuan meminta ijin kepada leluhur dan para dewa. Salah satu contoh dari faktor ketiga adalah individu yang mengalami kondisi sakit baik fisik ataupun psikis, dalam kondisi ini 
individu akan menjadi lemah dan mencari pertolongan dari pihak ketiga yaitu jero mangku dan solusi yang diberikan adalah upacara ngerawang.

Sebelum individu menyandang status sebagai seorang jero, individu merupakan bagian dari anggota keluarga dan anggota masyarakat. Hal tersebut menjadikan individu memiliki peran yang harus dilaksanakan. Pada lingkungan keluarga contoh peran yang dimiliki oleh individu misalnya, sebagai kepala rumah tangga, ibu rumah tangga, suami, istri, anak, dan lain sebagainya. Peran individu dalam anggota masyarakat misalnya, perangkat desa, warga banjar dan lain sebagainya. Terlepas dari status jero yang dimiliki, individu memiliki kebutuhan diri dan keluarga yang harus dipenuhi. Dalam sudut pandang ekonomis peran sebagai jero tidak menjanjikan untuk memberikan penghidupan dan penghasilan yang layak karena peran ini lebih dominan unsur ngayah oleh sebab itulah disamping berperan sebagai jero, individu wajib memiliki mata pencaharian yang stabil (Swandiana, 2009).

Kompleksitas peran yang dimiliki individu pasca menjadi seorang jero sangat meningkat. Pada awalnya peran yang dimiliki mungkin hanya sebatas sebagai anggota keluarga, anggota masyarakat dan pekerjaan. Pasca menjadi seorang jero terdapat tuntutan peran tambahan yang tidak mengenal waktu. Hal ini sesuai dengan pendapat Swadiana (2009) menambahkan bahwa disamping berprofesi sebagai jero, individu masih pula mencari penghidupan atau mata pencaharian sebagai Pegawai Negeri Sipil (PNS), pengusaha, buruh, pedagang, petani, dan lain sebagainya untuk memenuhi kebutuhan sehari-hari keluarga maupun kebutuhan sehari-hari. Kepentingankepentingan antara peran yang dimiliki saling bersinggungan yang dapat menimbulkan terjadinya permasalahan.

Bentuk permasalahan utama yang mungkin muncul dari kompleksitas peran adalah konflik peran. Menurut Winardi (2003) konflik peran adalah konflik yang terjadi karena seseorang mengemban lebih dari satu peran yang saling bertentangan. Muchlas (2008) membagi konflik peran menjadi tiga jenis. Jenis pertama adalah konflik antara orang dan peran. Konflik ini terjadi sebagai akibat dari pertentangan kepribadian individu dengan ekspektasi peran. Jenis kedua adalah konflik dalam peran. Konflik ini timbul akibat ekspektasi yang bertentangan antara bagaimana peran yang harus dimainkan dan peran yang dijalankan. Jenis ketiga adalah konflik antar peran. Konflik ini muncul akibat persyaratan berbeda antara peran-peran yang harus dijalankan dalam waktu yang bersamaan. Hal ini sesuai dengan hasil preliminary study pada JN mengatakan bahwa individu yang menjalankan peran sebagai jero di desa tempat tinggal JN sering mengalami konflik peran. Sebagai contoh individu harus memimpin suatu acara agama karena berperan sebagai jero dan pada waktu yang bersamaan individu harus bekerja mengajar di sekolah terkait profesinya sebagai seorang guru (Cempaka, 2017).

Menurut Riggio (2009) mengemukakan bahwa konflik peran harus diselesaikan apabila konflik yang ada mengarah pada hasil yang negatif, sedangkan ketika level konflik peran itu rendah hanya diperlukan stimulasi konflik. Individu dengan status jero di salah satu desa yang terletak di Kabupaten Bangli mengutamakan segala peran yang dimiliki dapat berjalan dengan optimal. Pada situasi ketika harus menjalankan beberapa peran saat waktu yang bersamaan. Individu dengan status jero akan mengupayakan kewajiban yang dimiliki dapat berjalan dengan optimal, baik peran sebagai jero atau peranperan lainnya (Cempaka, 2017). Salah satu resolusi konflik peran yang dapat dilakukan oleh individu adalah dengan mengelola waktu yang dimiliki atau bisa disebut dengan time management.

Macan (dalam Rusyadi, 2017) mendeskripsikan manajemen waktu sebagai pengelolaan waktu, sehingga individu menetapkan terlebih dahulu kebutuhan dan keinginan kemudian menyusunnya berdasarkan segi urutan kepentingan, sehingga individu dengan peran sebagai jero dapat melaksanakan kewajiban dan tanggung jawab yang diemban dengan baik. Berdasarkan pemaparan di atas, peneliti tertarik melakukan penelitian untuk melihat bagaimana konflik peran yang terjadi dan penyelesaian konflik pada jero yang menjalani prosesi ngerawang di Kabupaten Bangli.

\section{METODE PENELITIAN}

\section{Tipe Penelitian}

Metode penelitian yang akan digunakan adalah metode penelitian kualitatif dengan pendekatan studi kasus. Bogdan dan Taylor (dalam Moleong, 2014) mendefinisikan metodologi kualitatif sebagai prosedur penelitian yang menghasilkan data deskriptif berupa kata-kata tertulis atau lisan dari orang-orang dan perilaku yang dapat diamati. Menurut Gunawan (2016) penelitian studi kasus merupakan studi mendalam mengenai unit sosial tertentu dan hasil penelitian tersebut memberikan gambaran luas, serta mendalam mengenai unit sosial tertentu, sedangkan menurut Creswell (dalam Gunawan, 2016) mengatakan bahwa penelitian studi kasus adalah penelitian yang dilakukan terhadap suatu objek, yang disebut sebagai kasus, yang dilakukan secara seutuhnya menyeluruh dan mendalam dengan menggunakan berbagai macam sumber dan data.

Peneliti menggunakan pendekatan studi kasus karena peneliti menemukan suatu permasalahan atau peristiwa, peneliti ingin memahami suatu masalah dan memungkinkan dikembangkan dalam suatu kerangka analisis untuk dapat memecahkan suatu peristiwa atau permasalahan (Bungin, 2007). Pendekatan studi kasus digunakan karena keunikan penelitian studi kasus yaitu cara pandang terhadap objek penelitiannya sebagai sebuah kasus (Gunawan, 2016).

\section{Responden Penelitian}

Teknik pemilihan responden yang digunakan adalah teknik purposive sampling. Kriteria responden yang digunakan dapat dijelaskan sebagai berikut:

1. Individu yang mejalani prosesi upacara ngerawang/eka jati di Kabupaten Bangli dengan proses pemilihan ditunjuk oleh paduluan adat dan upacara nyanjan/matuun

2. Berjenis kelamin laki-laki dan perempuan

3. Berusia 35 dan 24 tahun

4. Berasal dari Kabupaten Bangli 
5. Berdomisili di Bali

6. Memiliki peran lain selain peran sebagai seorang jero yaitu responden pertama memiliki peran sebagai guru, wakil kepala sekolah dan petani, sedangkan responden kedua memiliki peran sebagai seorang bidan. Informan dalam penelitian ini akan dipilih pihak-pihak yang merupakan significant other responden, diantaranya keluarga tinggal ditempat yang sama dengan responden penelitian.

\section{Teknik Penggalian Data}

Dalam Penelitian ini, teknik pengumpulan data yang digunakan adalah wawancara dan observasi yang dijelaskan sebagai berikut:

\section{Wawancara}

Wawancara adalah suatu percakapan yang diarahkan pada suatu masalah tertentu dan merupakan proses tanya jawab lisan dimana dua orang atau lebih berhadapan secara fisik Setyadin (dalam Gunawan 2016). Wawancara dilakukan untuk memperoleh data atau informasi sebanyak mungkin dan sejelas mungkin kepada subjek penelitian. Di dalam penelitian ini, peneliti menggunakan teknik pengambilan data dengan wawancara semiterstruktur karena peneliti tetap menggunakan guideline wawancara sebagai panduan pada saat wawancara dilaksanakan dan peneliti memberikan kesempatan pada responden untuk mengutarakan pendapat dan ide-idenya terkait konflik peran yang dialami oleh partisipan sebagai jero yang menjalani prosesi ngerawang di Kabupaten Bangli.

\section{Observasi}

Menururt Kartono (dalam Gunawan, 2016) pengertian observasi ialah studi yang disengaja dan sistematis tentang fenomena sosial, gejala-gejala psikis dengan jalan pengamatan dan pencatatan. Istilah observasi diarahkan pada kegiatan memperhatikan secara akurat, mencatat fenomena yang muncul, dan mempertimbangkan hubungan antaraspek dalam fenomena tersebut (Gunawan, 2016). Pada penelitian ini, peneliti menggunakan teknik pengambilan data participant observation (observasi berperan serta) dalam observasi ini, peneliti terlibat dengan kegiatan sehari-hari individu yang menjadi subjek penelitian. Penelitian ini menggunakan teknik pengambilan data observasi karena peneliti ingin melihat secara alamiah kegiatan-kegiatan yang dilakukan oleh partisipan dalam menjalankan perannya sebagai seorang jero tanpa merasa diamati (Moleong, 2014).

\section{Teknik Analisis Data}

Semua pencatatan atau perekaman data dapat dikategorikan catatan lapangan (fieldnotes). Analisis dilakukan dengan menggunakan model analisis data yang dikembangkan oleh Strauss dan Corbin (2009). Model analisis data ini dikenal dengan model theoretical coding, yang mana terdiri dari tiga tahapan yaitu open coding, axial coding, dan selective coding. Open coding, axial coding, dan selective coding. Open coding adalah proses merinci, menguji, mengkonseptualisasikan dan melakukan kategorisasi data. Axial coding adalah proses yang dilakukan dengan membuat kaitan antara kategori-kategori yang telah dibuat. Selective coding adalah proses untuk menentukan kategori inti, dengan menghubungkan secara sistematis ke kategori-kategori lain melakukan validasi hubungan-hubungan antar data dan memasukkannya ke dalam kategori-kategori yang diperlukan lebih lanjut untuk melakukan perbaikan dan pengembangan (Strauss \& Corbin, 2013).

\section{HASIL PENELITIAN}

Terkait dengan desain penelitian yang peneliti gunakan dalam penelitian ini, yaitu desain penelitian studi kasus, maka pada hasil penelitian akan dipaparkan secara terpisah tiap kasus responden. Segala hal yang dituangkan dalam bagian hasil penelitian ini merupakan fakta hasil temuan dari proses pengumpulan data yang telah melalui tahap analisis data. Hasil penelitian pada tiap responden akan dibagi menjadi dua kategori, yaitu kategori pengalaman awal responden, dan kategori konflik peran.

\section{Kategori 1: Pengalaman awal responden ( Kasus jero yang ditunjuk)}

Pengalaman awal responden sebelum menjadi seorang jero diawali dengan ditunjuknya responden oleh pengurus desa adat sebagai jero nyarikan, namun dikarenakan responden memiliki peran lain yang membutuhkan konsentrasi penuh membuat responden menolak untuk menjadi seorang jero. penolakan yang dilakukan responden menimbulkan permasalahan yang terjadi pada diri responden, sehingga dengan semakin banyak masalah yang dialami oleh responden membuat responden menerima dan melaksanakan prosesi upacara ngerawang dan menjadi seorang jero. Hal tersebut dapat dijelaskan pada gambar berikut (terlampir).

Pengalaman Awal

Pengalaman awal responden menjadi seorang jero diawali dengan ditunjuknya responden oleh beberapa orang yang berpengaruh di desa tempat tinggalnya dan keluarga besar responden. Sekitar tujuh tahun yang lalu responden diminta untuk menjadi seorang jero oleh beberapa prajuru adat desa, namun pada saat itu responden belum memberikan keputusan dari penunjukkan tersebut.

Dipilih dan menolak

Pada awalnya responden menolak menjadi seorang jero karena kesibukan pekerjaan. Responden bekerja menjadi seorang guru disalah satu sekolah di Kota Bangli dan jarak yang harus ditempuh oleh responden kurang lebih $30 \mathrm{~km}$, sehingga membuat responden sangat mempertimbangkan keputusannya sebagai seorang jero. Responden merasa bahwa kewajiban menjadi seorang jero dianggap sebagai tugas kerohanian yang tidak mendapatkan manfaat khususnya dari segi finansial dan membuat responden merasa kewalahan dengan berbagai macam peran yang harus dijalaninya ketika menjadi seorang jero.

\section{Muncul permasalahan}

Penolakan yang dilakukan responden terkait dengan ditunjuknya responden menjadi seorang jero menimbulkan permasalahan. Permasalahan-permasalahan yang muncul terkait dengan penolakan yang dilakukan responden dan keluarga menimbulkan dampak terhadap diri responden sendiri, keluarga bahkan terhadap anak responden. Permasalahanpermasalahan yang muncul terkait dengan penolakan yang dilakukan responden dan keluarga menimbulkan dampak terhadap diri responden sendiri, keluarga bahkan terhadap anak responden. Responden merasa munculnya masalah dengan keluarga merupakan salah satu dampak dari penolakan yang 
dilakukan responden. Salah satu permasalahan yang muncul terkait dengan penolakan ini salah satu anak responden mengalami suatu penyakit.

\section{Menerima}

Penerimaan diri responden sebagai seorang jero akhirnya dilakukan terkait dengan permasalahan-permasalahan yang muncul akibat penolakan yang dilakukan oleh responden dan keluarga, sehingga responden akhirnya harus menerima secara tulus bahwa diri resoponden harus melaksanakan upacara ngerawang/eka jati dan menjadi seorang jero. Banyak perubahan yang terjadi terkait dengan status responden menjadi seorang jero. Perlakuan keluarga besar, anak, istri hingga beberapa teman di tempat kerjanya membuat responden merasa berbeda. Mulai dari cara bicara perlakuan memberi makanan dirasakan oleh responden, sehingga responden berusaha untuk menyesuaikan diri hingga saat ini dengan perubahan-perubahan dan batasan yang terjadi.

Terkait dengan penjelasan diatas, hal tersebut dapat diperkuat dengan kutipan-kutipan dibawah ini:

"Kebetulan sekitar 8 tahun yang lalu memang ee.. diarahkan untuk jadi jero oleh keluarga, dari paduluan pakramandesa sebetulnya" (VR1GD-1L33-34).

"Perasaan ya terpaksa merasa terpaksa menjadi jero, menjadi jero itu perlu saya garis bawahi, bahwa disini kita akan melaksanakan kewajiban, yang secara finansial sebetulnya tidak dapat apa-apa, tetapi kita melaksanakan kewajiban ini karena memang betul-betul karena tugas secara niskala, secara rohani yang memang, memang itu adalah tugas kita beban kita" (VR1GD-1L43-46).

\section{Kategori 2: Konflik Peran (Kasus jero yang ditunjuk)}

Konflik peran pada responden terjadi akibat benturan antar peran yang dimiliki. Responden GD bekerja menjadi seorang guru disalah satu sekolah di Kabupaten Bangli, selain menjadi seorang guru responden juga menjalankan peran sebagai wakil kepala sekolah. Peran-peran lain seperti peran sebagai suami dan ayah menambah peran dalam diri responden, hal tersebut membuat konflik antar peran terjadi akibat berbagaimacam peran yang harus dijalani responden dan konflik tersebut berdampak pada diri dan keluarga responden. Hal tersebut dapat dijelaskan pada gambar berikut (terlampir).

\section{Konflik peran}

Menjadi seorang jero membuat tanggung jawab responden semakin bertambah. Tidak hanya tanggung jawab kepada Tuhan Yang Maha Esa, namun tanggung jawab kepada masyarakat dan pekerjaan juga membuat responden harus menjalankan peran-peran yang dimiliki dengan baik. Adanya perbedaan antara harapan-harapan yang berkaitan dengan suatu peran dengan peran lainnya dapat memicu timbulnya konflik antar peran yang dimiliki. Berbagai macam dampak yang akan terjadi seiring semakin meningkatnya konflik peran yang dihadapi oleh individu, sehingga sangat dibutuhkan solusi dalam penyelesaian konflik peran tersebut. Responden merasakan timbulnya banyak konflik dalam diri responden salah satunya diakibatkan oleh peran-peran yang dijalani.

Peran

Melalui proses penunjukan dari beberapa pihak desa responden akhirnya melaksanakan prosesi upacara ngerawang/eka jati, sehingga responden menjadi seorang jero nyarikan. Responden memegang peran sebagai sekretaris desa, bendahara, dan sekaligus menjadi pelaksana atau pemimpin dalam upacara agama tertentu. Responden juga memiliki peran penting dalam keluarganya. Responden menjadi seorang kepala keluarga sekaligus menjalankan peran sebagai seorang ayah bagi ketiga anak responden. Sebelum menjadi seorang jero, responden merupakan seorang PNS yang bekerja menjadi seorang guru di suatu sekolah menengah atas yang terletak di Kabupaten Bangli. Pekerjaan menjadi seorang guru merupakan pekerjaan utama responden, sehingga pekerjaan sebagai guru lebih didahulukan dari pekerjaan lainnya terkait degan kontrak kerja sebagai PNS. Responden selama menjalankan peran sebagai seorang guru dan jero juga menyempatkan diri untuk melanjutkan program studi S2, namun responden merasakan bahwa dengan melanjutkan sekolahnya tersebut membuat peran-peran yang dimiliki semakin bertambah.

Konflik yang muncul

Responden merasa bahwa peran-peran yang sedang dijalani merupakan penyebab dari konflik yang sedang dihadapi. Selain itu kurangnya waktu juga merupakan salah satu penyebab dari konflik yang dihadapi oleh responden. Responden juga menceritakan bahwa anak-anak responden kerap menuntut agar lebih membimbing dalam bidang akademik. Responden juga kerap mengalami konflik dengan istri yang diakibatkan waktu yang kurang cukup bersama keluarga dan responden merasa bahwa konflik peran yang dialami saat ini terjadi di sekolah terutama pada proses pembelajaran. terjadi konflik dalam diri yang membuat diri responden merasa sangat stress dan berpengaruh dalam performa kerja responden, sehingga dapat dikatakan bahwa Responden juga mengalami berbagai konflik batin salah satunya berpengaruh terhadap pola tidur responden yang membuat tugas dan kewajiban tidak berjalan dengan baik. Dampak

Responden mengatakan bahwa konflik peran yang dialami oleh responden berdampak pada orang-orang disekitar responden, seperti keluarga, teman di kantor, dan juga berdampak pada kegiatan-kegiatan keagamaan yang harus tertunda dikarenakan responden masih menjalankan peran lainnya. Kesibukan yang dikarenakan peran yang dimiliki membuat responden merasa asing di keluarga besar karena kehadiran responden yang cukup terbilang jarang untuk dapat mengikuti acara keluarga. Responden lebih mengorbankan dirinya sendiri seperti mengurangi jam tidur agar peran-peran dapat berjalan dengan baik.

$\underline{\text { Solusi }}$

Time management adalah salah satu solusi pemecahan masalah yang dilakukan. Mengatur jadwal antara peran satu dengan peran lainnya adalah salah satu cara yang dilakukan responden agar peran-peran yang dimiliki responden tidak mengalami benturan. Cara lainnya agar peran-peran responden dapar berjalan dengan baik adalah dengan mengurahi jam tidur responden. Solusi selanjutnya adalah dengan cara tugas-tugas dan kewajiban responden digantikan oleh orang-orang disekitarnya. Orangtua dan istri responden sering menggantikan posisi responden agar peran-peran yang tidak dapat dilaksanakan bisa berjalan dengan baik, seperti menghadiri acara keluarga atau pun mengasuh anak seringkali digantikan oleh istri ataupun orangtua responden dan penambahan anggota jero nyarikan baru akan memudahkan dan meringankan dampak dari konflik peran tersebut. 
Terkait dengan penjelasan diatas, hal tersebut dapat diperkuat dengan kutipan-kutipan dibawah ini:

"Sebagai manusia biasa tentunya apalagi menjadi jero seperti saya, emang selalu multi peran yang saya jalani, menjadi guru, menjadi jero, selain menjadi kepala keluarga disisi lain karena saya orang desa juga menjalankan, menjalankan pekerjaan lain sebegai petani juga, bersama dengan istri" (VR1GD-1L233236).

\section{Kategori 3: Pengalaman Awal (Kasus jero yang melakukan nyanjan/matuun)}

Perbedaan pengalaman awal responden kedua AN dengan responden pertama GD terletak pada proses awal melaksanakan prosesi ngerawang. Responden AN mengalami suatu penyakit ketika responden berumur tiga bulan, sehingga keluarga besar responden AN melaksanakan upacara nyanjan/matuundan dilanjutkan dengan upacara ngerawang tanpa adanya penolakan dari keluarga dan responden AN menjalani prosesi upacara ngerawang saat responden AN telah siap menjalani tugas dan kewajiban seorang jero. Hal tersebut dapat dijelaskan pada gambar berikut (terlampir).

Pengalaman awal

Sebelum responden menjadi seorang jero pada awalnya responden mengalami suatu penyakit yang tidak bisa disembuhkan selama hampir tiga bulan, berbagai upaya penyebuhan dengan jalan medis sudah ditempuh oleh keluarga responden, namun tidak membuahkan hasil yang maksimal. keluarga sudah mencari cara agar responden dapat sembuh dari penyakitnya tersebut, hingga cara terakhir yaitu nyanjan/matuun menjadi pilihan terakhir keluarga. Keputusan dari proses nyanjan/matuun responden harus melaksanakan upacara ngerawang, namun karena masih balita keluarga menunda pelaksanaan upacara tersebut.

$\underline{\text { Sakit }}$

Responden mengalami suatu penyakit saat balita. Menurut cerita yang responden dengar responden mengalami sakit yang tidak kunjung sembuh, suhu tubuh responden sangat tinggi selama beberapa minggu, namun penyakit tersebut secara perlahan sembuh ketika responden melaksanakan upacara nyanjan/matuun dan selanjutnya melaksanakan prosesi upacara ngerawang/eka jati dan menjadi seorang jero, walaupun pada saat itu tugas dan kewajiban belum bisa sepenuhnya dilaksanakan oleh responden.

Menjadi seorang jero

Tidak ada penolakan dari pihak manapun terkait dengan pelaksanaan upacara ngerawang/eka jati dan menjadikan responden sebagai seorang jero. Keluarga responden menerima dan dan tidak menolak karena penyakit yang dialami oleh responden tidak pulih, sehingga tidak ada penolakan dari pihak manapun, namun dikarenakan responden belum cukup umur pelaksanaan prosesi upacara ngerawang dilaksanakan saat responden memasuki bangku sekolah dasar.

Perubahan dan respon masyarakat

Responden merasa bahwa masyarakat terutama teman-teman sekolah responden memiliki respon yang berbeda dengan lingkungan rumah responden yang memang cenderung menerima. Teman-teman responden ketika SMA cenderung melihat peran responden menjadi jero adalah suatu hal yang aneh dan tabu. Tidak jarang ejekan yang dilontarkan oleh teman-teman responden.

Terkait dengan penjelasan diatas, hal tersebut dapat diperkuat dengan kutipan-kutipan dibawah ini:

"karena gak sembuh diajak ke sri mpu kayak istilah kayak orang bali di tunasin gitu ya harus di buatin mewinten jadi jero" (VR2AN-1L74-75).

"katanya sih dulu karena sakit-sakitan terus ee udah di bawa ke medis juga gak sembuh-sembuh. Akhirnya di tanyain ke orang pintar kayak Sri Mpu gitu” (VR2AN-1L48-49)

\section{Kategori 4: Konflik Peran (Kasus jero yang melakukan nyanjan/matuun)}

Sama seperti kasus yang dialami oleh responden pertama, responden kedua juga mengalami konflik peran yang diakibatkan oleh peran-peran yang dijalani saat ini. Responden kedua memiliki peran utama selain menjadi seorang jero adalah sebagai seorang bidan di Puskesmas dan klinik bersama yang terletak di Kabupaten Bangli. Dengan menjalankan peran-peran tersebut, responden kerap mengalami konflik antar peran sebagai jero dan peran sebagai bidan. Responden juga kerap meminta ijin kepada atasan di tempat kerja responden agar dapat menjalani peran sebagai seorang jero. Hal tersebut dapat dijelaskan pada gambar berikut(terlampir).

$\underline{\text { Konflik Peran }}$

Adanya benturan antara harapan-harapan yang berkaitan dengan suatu peran dengan peran lainnya dapat memicu timbulnya konflik antar peran yang dimiliki. Berbagai macam dampak yang akan terjadi seiring semakin meningkatnya konflik peran yang dihadapi oleh individu, sehingga sangat dibutuhkan solusi dalam penyelesaian konflik peran tersebut

\section{Peran}

Berbagai tugas harus dilaksanakan dan berbagai aturan harus ditaati oleh responden sebagai seorang jero, seperti tidak boleh mengunakan barang tertentu secara bersamaan dengan orang lain, tidak boleh tidur dibawah lantai dan meminta makanan ditempat orang yang sedang mempunyai acara tertentu. Responden juga mengatakan bahwa harus ada niat yang tulus ketika menjalankan tugasnya sebagai seorang jero, seperti ngayah di Pura, nganteb banten, dan melaksanakan tugas-tugas lainnya. Peran atau pekerjaan utama responden adalah sebagai seorang bidan yang bekerja di Puskesmas dan klinik bersama di Kabupaten Bangli. Banyaknya tugas yang dilakukan oleh responden dikarenakan minimnya tenaga kerja yang bertugas di Puskesmas atau di klinik tempat responden bekerja, sehingga responden melaksanakan tugas melebihi perannya sebagai bidan.

Konflik yang muncul

Berbagai macam tuntutan dari keluarga yang meminta agar ada waktu luang untuk menghadiri acara keluarga. Tidak hanya itu, responden mengatakan bahwa temaan-teman dan atasannya kerap bertanya mengapa responden selalu sibuk ketika ada upacara agama. Responden juga mengatakan bahwa atasannya pernah menegur akibat seringnya responden meminta ijin tidak bekerja. Responden menambahkan jika konflik yang terjadi antara perannya sebagai jero dan bidan membuat responden harus bisa mengatur waktunya baik itu meminta ijin dengan atasan atau meminta penukaran jadwal dengan teman responden. 


\section{Dampak}

Konflik peran ini berdampak pada kurangnya waktu bersama keluarga. Responden sering tidak bisa hadir dalam acara-acara keluarga, sehingga responden jarang bertemu dengan keluarganya yang diakibatkan tugas dan peran yang harus dijalankan. Masyarakat juga terkena dampak dari masalah ini. Masyarakat yang akan berobat akan menunggu karena responden sedang menjalankan peran lainnya, namun itu sering terjadi di tempat praktek ibu responden. Responden memiliki seorang pacar yang juga sama-sama berasal dari Kabupaten Bangli, namun pacar responden kedua ini tidak tinggal di kota yang sama, melainkan bekerja dan tinggal di Kota Denpasar. Responden mengatakan bahwa pacar responden sering mengeluh karena responden tidak memiliki waktu.

$\underline{\text { Solusi }}$

Menurut Responden salah satu solusi yang baik dalam mengurangi konflik peran yang terjadi adalah dengan time management dengan cara membagi waktu. Mengatur jadwal dengan rekan kerja responden adalah salah satu solusi yang sering dilakukan oleh responden. Ketika kedua peran responden sangat membutuhkan responden dalam waktu bersamaan, responden akan memilih peran mana yang lebih memungkinkan untuk ditinggalkan. Salah satu solusi yang dapat dilakukan ketika responden harus hadir dalam upacara agama dan harus meninggalkan tempat kerja responden yaitu dengan meminta teman yang menggantikan jadwal kerja.

Terkait dengan penjelasan diatas, hal tersebut dapat diperkuat dengan kutipan-kutipan dibawah ini:

"Sangat sering, sering banget apa namanya peran itu bersamaan pas misalkan saya pas jadwalnya jaga, kadang pas ada odalan sering banget, jadinya saya harus merelakan salah satunya" (VR2AN-1L249-251).

"Sangat sering, sering banget apa namanya peran itu bersamaan pas misalkan saya pas jadwalnya jaga, kadang pas ada odalan sering banget, jadinya saya harus merelakan salah satunya" (VR2AN-1L249-251).

\section{PEMBAHASAN DAN KESIMPULAN}

Berdasarkan penelitian yang telah dilakukan, diperoleh hasil bahwa konflik pada jero yang menjalani prosesi ngerawang baik dengan proses ditunjuknya responden oleh keluarga besar ataupun dengan alasan sakit dan melaksanakan prosesi nyanjan/matuun cenderung memiliki permasalahan yang sama yaitu terbenturnya pelaksanaan dan kewajiban dari peran-peran yang dimiliki. Hasil penelitian ini menunjukkan terdapat dua tema temuan yang dihasilkan oleh kedua responden, yaitu tema pertama adalah pengalaman awal responden dan tema kedua adalah konflik peran dan penyelesaian konflik yang dilakukan oleh responden. Pada kategori pertama yaitu pengalaman awal individu sebelum dan hingga menjadi seorang jero terdapat perbedaan dinamika yang akan dipaparkan dalam pembahasan hasil berikut:

\section{Dinamika kategori pengalaman awal dalam proses individu menjadi seorang jero}

Kategori awal adalah kategori individu menjadi seorang jero dengan alasan tertentu, sehingga dengan melaksanakan prosesi upacara ngerawang/eka jati individu dapat melaksanakan tugas dan tanggung jawab sebagai seorang jero. Warna, dkk., (dalam, Sugiarta \& Adnyana 2013) menyebutkan bahwa Pawintenan atau Eka Jati diartikan sebagai upacara penyucian diri. Sugiarta dan Adnyana (2013) mengatakan bahwa proses ini dapat dikatakan sebagai formalitas awal secara jasmani dan rohani bagi individu yang akan melaksanakan upacara ngerawang yang merupakan istilah masyarakat salah satu desa di Kabupaten Bangli dari pengertian eka jati atau pawintenan.

Proses pemilihan seorang jero berbeda-beda tiap orangnya. Sudharta, dkk., (1991) mengatakan bahwa pemilihan dan penetapan seorang jero baik jero mangku ataupun sebutansebutan yang digunakan di daerah-daerah lainnya, pada umumnya diambil dari para penyungsung pura yang bersangkutan. Kedua responden pada penelitian ini melaksanakan prosesi upacara ngerawang/eka jati dikarenakan responden ditunjuk dan mengalami suatu penyakit dan melaksanakan upacara nyanjan/matuun dan dilanjutkan dengan prosesi upacara ngerawang. Sejalan dengan hal tersebut Sudharta, dkk., (1991) mengatakan cara penentuan yang sering terjadi di daerah-daerah Bali adalah dengan melalui pemilihan dari prajuru (pengurus) atau keluarga besar individu yang ditunjuk.

Sudharta, dkk., (1991) menambahkan bahwa seseorang yang ditunjuk menjadi jero dengan proses pemilihan akan bertugas ngeloka parasraya yaitu sebagai sandaran umat di dunia dalam melayani kegiatan yang berhubungan dengan upacara yadnya, sehingga individu yang dipilih haruslah yang sudah menikah agar pelaksanaan tugas yang diemban dapat berjalan dengan baik bila dikerjakan bersama pasangan. Orang yang sudah menikah memiliki dukungan emosi dari pasangan masingmasing, sehingga dalam melaksanakan tugas dan kewajiban individu yang telah menikah akan memiliki rasa tanggung jawab yang tinggi dibandingkan individu yang tidak memiliki pasangan (Lestari, 2012).

Berbeda halnya dengan individu yang melaksanakan upacara ngerawang/eka jati dengan cara nyanjan/matuun yang disebabkan oleh suatu penyakit atau kesialan yang terus menerus terjadi dalam kehidupan individu, sehingga pelaksanaan nyanjan/matuun adalah salah satu cara pencarian solusi dari permasalahan yang dimiliki. Sudharta, dkk., (1991) menyebutkan bahwa pelaksanaan nyanjan atau matuun ini umumnya dilaksanakan di pura dengan mengundang beberapa jero yang berada di desa individu tinggal. Setelah dilaksanakan atur piuning dengan upacara menggunakan pejati secukupnya serta kelengkapan upakara yang disiapkan, mulailah dilakukan pemujaan dan persembahyangan bersama. Dalam keadaan kerauhan (kesurupan), jero yang bertugas memimpin upacara tersebut menyebutkan nama individu yang harus melaksanakan upacara ngerawang/eka jati.

Sudharta, dkk., (1991) menambahkan bahwa pelaksanaan upacara nyanjan/matuun akan dianggap berhasil bilamana yang ditunjuk merupakan orang yang memiliki suatu penyakit dan kesialan dalam hidupnya dan telah meyakinkan seluruh orangorang yang ada dalam upacara tersebut. Melalui proses nyanjan atau matuun biasanya baik individu yang ditunjuk tidak berani 
menolak dan dapat menerima dengan keyakinan yang tulus. Pelaksanaan prosesi upacara nyanjan/matuun dapat dilakukan oleh orang-orang dari kalangan apapun, tidak terbatas usia baik individu pada fase balita hingga dewasa akhir dan dengan status menikah atau belum menikah, karena pelaksanaan prosesi upacara nyanjan/matuun dapat dilaksanakan terkait masalahmasalah yang terjadi pada individu (Dalu, 2011). Tugas dan kewajiban seorang jero pada umumnya telah diatur dalam awig-awig desa adat. Secara umum tugas dan kewajiban jero adalah mengantarkan upacara yadnya pada batas kewenangan yang telah ditetapkan (Sudharta dkk., 1991).

Penolakan dari diri sendiri maupun penolakan yang dilakukan oleh keluarga banyak dilakukan terkait peran seorang jero dan tugas-tugas yang akan diemban oleh individu, baik individu yang sudah menjadi jero melalui proses pemilihan oleh prajuru desa adat ataupun melalui proses nyanjan atau matuun karena tidak seperti jabatan-jabatan lainnya, jabatan sebagai seorang jero sangat tidak banyak diminati orang dan sedikit sekali dan mungkin tidak ada anak-anak muda yang secara tulus bercitacita menjadi seorang jero (Swadiana, 2009). Penolakan juga dilakukan terkait dengan peran lain yang dimiliki oleh individu atau umur yang masih belum bisa mengemban tugas dan kewajiban seorang jero.

Sudharta, dkk., (1991) mengatakan bahwa dengan cara pemilihan secara langsung terhadap seorang individu yang akan menjadi seorang jero memang tidak luput dari segi baik dan lemahnya. Segi baiknya, jero yang dipilih dan ditetapkan didasarkan atas kesepakatan bersama oleh keluarga maupun prajuru adat, sedangkan kelemahannya akan kesulitan mencari calon jero yang betul-betul bersedia dan juga didukung oleh seluruh penyungsung pura yang bersangkutan. Sama halnya dengan individu yang menjadi seorang jero melalui prosesi nyanjan/matuun ketika seseorang mengalami kesulitan dalam hidupnya dan melaksanakan upacara nyanjan/matuun sebagai pencarian solusi terhadap masalah yang dihadapi, tidak sedikit juga menunda bahkan merasa tidak siap dengan peran yang harus dijalani. Disamping karena kalau dipandang dari segi ekonomis, profesi sebagai seorang jero tidak menjanjikan untuk memberikan penghidupan dan penghasilan yang layak karena profesi ini lebih dominan unsur ngayah dari pada sisi lainnya (Swadiana, 2009).

Penundaan dan penolakan yang dilakukan oleh individu dengan status jero salah satunya dikarenakan oleh ketidaksiapan terhadap suatu peristiwa yang akan terjadi dimasa depan atau belum sepenuhnya seseorang untuk menerima kondisi dirinya saat ini. Hal itu juga dikarenakan seorang pemimpin agama atau jero dalam kehidupan sehari-harinya masih harus berkutat dengan masalah kebutuhan rumah tangga, mempunyai istri dan anak-anak serta keluarga yang perlu diberi nafkah (Swadiana, 2009). Menurut kepercayaan masyarakat desa di Kabupaten Bangli, dampak dari penundaan individu terhadap pelaksanaan upacara ngerawang/eka jati adalah akan mengalami permasalahan yang tidak kunjung selesai dan ketika individu menolak untuk melaksanakan upacara ngerawang permasalahan akan semakin terlihat dengan kejadian-kejadian buruk yang akan terjadi kepada individu terkait dengan penundaan dan penolakan yang dilakukan, sehingga banyak dari individu yang menerima baik secara tulus ikhlas ataupun dengan perasaan terpaksa melaksanakan upacara ngerawang/eka jati dan menjadi seorang jero.

\section{Dinamika kategori konflik peran dan penyelesaian konflik individu dengan status jero}

Kategori kedua atau kategori konflik peran dan penyelesaian konflik adalah kategori munculnya konflik serta dampak yang ditimbulkan oleh konflik peran yang dimiliki oleh individu dengan status jero, hingga bagaimana penyelesaian konflik yang dilakukan. Selain bertugas untuk melakukan yadnya, individu-individu dengan status jero tersebut juga masih melakukan kegiatan lain seperti umat kebanyakan yakni mencari nafkah untuk memenuhi kebutuhan sehari-hari.

Menurut Swadiana (2009) disamping berprofesi sebagai jero atau permangku, individu tersebut masih juga mencari mata pencaharian sebagai PNS (Pegawai Negeri Sipil), pengusaha, dokter, guru, petani, dan profesi lainnya. Jero yang dipilih melalui proses pemilihan oleh prajuru adat pada penelitian ini memiliki peran lain yaitu sebagai seorang guru dan petani. Menurut Poerwadarminta (2009) guru merupakan individu yang bertugas untuk mengajar. Tugas dan tanggung jawab guru adalah mengajar atau menyampaikan kewajiban kepada peserta didik, serta membimbing anak didik secara keseluruhan agar menjadi pribadi yang baik. Peran lain yang dijalani adalah sebagai petani yang bertugas dalam mengelola pertanian yang bertujuan untuk memelihara tanaman dengan harapan dapat memperoleh hasil dari tanaman tersebut. Hal ini yang mengakibatkan individu dengan status jero tidak bisa mencurahkan seluruh perhatiannya sebagai seorang jero atau pemangku.

Swadiana (2009) menyebutkan bahwa kesibukan atau keterbatasan waktu serta masih banyaknya gesekan-gesekan dengan kehidupan sehari-hari, menyebabkan individu dengan status jero tidak banyak memiliki waktu untuk meningkatkan pengetahuan serta menjaga kesucian dirinya, hal tersebut dapat menimbulkan konflik yang terjadi akibat peran-peran yang dimiliki oleh individu dengan status jero. Menurut Lestari (2012) konflik merupakan peristiwa sosial yang mencangkup penentangan (oposisi) atau ketidaksetujuan. Konflik antarpribadi dapat bermanfaat dan merugikan tergantung pada strategi yang digunakan untuk mengelola konflik itu sendiri. Konflik yang muncul pada individu dapat berupa konflik eksternal (berasal dari luar individu) dan konflik internal (berasal dari dalam diri individu). Kedua individu dengan status jero baik dengan pemilihan melalui proses dipilih oleh prajuru adat desa ataupun melalui prosesi nyanjan/ngerawang mengalami konflik internal dan eksternal.

Konflik eksternal yang terjadi pada individu dengan status jero yang dipilih melalui proses pemilihan oleh prajuru adat diakibatkan oleh tuntutan tugas dan kewajiban dari peran-peran yang dimiliki dan tuntutan untuk meluangkan lebih banyak waktu bersama keluarga. Defrain dan Stinnet (dalam Lestari, 2012) menyatakan bahwa dalam hubungan keluarga penting terdapat waktu yang berkualitas seperti makan bersama, bermain bersama dan bekerja bersama untuk mengurangi kesenjangan dan konflik yang terjadi dalam keluarga. Ketika 
waktu yang dihabiskan oleh individu lebih sedikit dari pada waktu bersama keluarga, maka akan berdampak pada keharmonisan hubungan antar anggota keluarga (Lestari, 2012). Pada jero dipenelitian ini yang dipilih melalui proses pemilihan oleh prajuru adat memiliki tugas sebagai sekretaris dan sekaligus bendahara dalam jalannya upacara, yang seharusnya memiliki waktu lebih banyak dalam mengatur jalannya upacara, namun seperti yang sudah dijelaskan oleh Swadiana (2009) bahwa seorang jero juga memiliki tuntutan pekerjaan lain untuk memenuhi kebutuhan sehari-hari, sehingga waktu yang dimiliki oleh jero yang memiliki pekerjaan diluar perannya sebagai seorang jero mengakibatkan tidak bisa mencurahkan seluruh perhatiannya dalam melaksanakan tugas dan kewajibannya seorang jero atau pemangku.

Konflik internal yang timbul adalah stres yang dirasakan ketika dihadapkan dengan tuntutan-tuntutan peran yang dimiliki oleh individu dengan status jero. Robbins (2001) menyatakan bahwa stres merupakan suatu kondisi yang menekan keadaan psikis seseorang dalam mencapai suatu kesempatan di mana untuk mencapai kesempatan tersebut terdapat batasan atau penghalang, sedangkan Weinberg dan Gould (2003) mendefinisiskan stres sebagai ketidakseimbangan antara tuntutan (fisik dan psikis) dan kemampuan memenuhinya, sehingga ketika dalam proses pemenuhan kebutuhan tersebut gagal dilakukan akan berdampak krusial terhadap individu. Dampak yang terlihat pada stres yang dialami oleh individu dengan status jero yang dipilih oleh prajuru adat adalah tidak masksimalnya hasil dari tugas dan kewajiban yang seharusnya dikerjakan, sehingga menimbulkan tingginya tingkatan stres yang dialami oleh individu dengan status jero.

Berbeda pada individu dengan status jero melalui proses upacara nyanjan/matuun pada penelitian ini memiliki peran lain yaitu peran sebagai bidan. Kebidanan adalah suatu bidang ilmu yang mempelajari keilmuan/seni dalam mempersiapkan kehamilan, menolong persalinan, nifas, menyusui dan menolong bayi baru lahir hingga balita, serta berfungsi untuk memberikan bantuan dan dukungan pada perempuan, keluarga, dan komunitasnya (Kemenkes, 2007). Statusnya sebagai seorang bidan dan jero membuat individu dengan status jero yang melalui prosesi nyanjan/matuun tidak bisa mencurahkan waktunya pada peran-peran yang dimiliki, sehingga menimbulkan konflik eksternal dan internal pada diri individu dengan status jero.

Kesibukan dan kurangnya waktu yang dimiliki oleh indvidu dengan status jero membuat kewajiban dan pekerjaannya sebagai seorang bidan tidak berjalan dengan baik, sehingga berdampak pada kualitas kerja individu yang akan diikuti oleh penurunan kinerja individu ditempat kerja. Salah satunya berdampak pada masyarakat dan pasien yang mebutuhkan bantuan dan juga penghasilan individu yang menurun seiring dengan teguran yang didapatkan oleh individu dengan status jero melalui proses nyanjan/matuun. Konflik eksternal yang terjadi pada individu dengan status jero melalui proses nyanjan/matuun disebabkan oleh tuntutan peran yang dimiliki, baik peran sebagai jero yang harus melaksanakan yadnya di pura dan tuntutan perannya sebagai seorang bidan yang harus melaksanakan tugas dan kewajiban menolong masyarakat sesuai dengan kewenangan yang diberikan dengan maksud meningkatkan kesehatan ibu dan anak dalam rangka tercapainya keluarga berkualitas (Sofyan, 2006).

Konflik internal yang timbul adalah rasa bersalah yang dirasakan oleh individu dengan status jero melalui proses nyanjan/matuun. May (dalam Feist \& Feist, 2010) rasa bersalah muncul saat manusia menyangkal potensinya, gagal melihat secara akurat kebutuhan dari sesamanya, atau lupa akan ketergantungannya dengan alam. Rasa bersalah yang dirasakan oleh jero yang melaksanakan prosesi upacara ngerawang dengan proses nyanjan/matuun dalam penelitian ini diakibatkan ketika individu tidak dapat melaksanakan tugas dan kewajiban dengan baik, terlebih ketika tidak dapat melaksanakan tugas dan kewajiban seorang jero yang bertugas dalam pelaksanaan upacara yadnya. Dampak yang terlihat pada konflik internal yang terjadi adalah pasien atau masayarakat yang membutuhkan peran individu dengan status jero tidak ditangani dengan baik.

Pemecahan masalah terhadap konflik peran yang dilakukan individu dengan status jero baik dengan proses pemilihan oleh prajuru adat atau jero dengan proses nyanjan/matuun memiliki solusi yang sama yaitu dengan time management. Menururt Singh dan Jain (dalam Gea, 2014) time management adalah tindakan atau proses perencanaan dan pelaksanaan pantauan sadar atas sejumlah waktu yang digunakan untuk aktivitas khusus, terutama untuk meningkatkan efektivitas, efisiensi, dan produktivitas. Time management adalah perencanaan hari/waktu agar dapat menggunakan waktu dengan baik atas waktu yang dimiliki (Gea, 2014). Pengaturan waktu merupakan hal yang penting agar dapat menyelaraskan semua kegiatan yang dimiliki agar dapat berjalan dengan baik tanpa merugikan pekerjaan lainnya.

Menurut Forsyth (2009) menggunakan managemen waktu yang baik dapat berdampak seperti memiliki prioritas yang jelas dalam bekerja serta memiliki kemampuan untuk berkonsentrasi terhadap pekerjaan, sehingga dapat meningkatkan produktivitas kerja yang baik. Individu dengan status jero baik dengan proses pemilihan oleh prajuru adat atau jero dengan proses nyanjan/matuun yang mengelola waktunya dengan baik secara otomatis akan menurunkan kemungkinan timbulnya konflik yang terjadi pada tiap peran yang dimiliki, sehingga dampak yang dihasilkan oleh konflik peran yang terjadi akan semakin menurun.

Pemecahan masalah dengan time management sangat efektif dilakukan untuk mengurangi terjadinya konflik antara peran jero dengan peran lainnya yang dijalani oleh individu dengan status jero. Solusi lainnya dilakukan oleh jero yang dipilih melalui proses nyanjan/matuun dalam penelitian ini adalah dengan meminta perannya digantikan oleh orang lain, seperti digantikan oleh ibu atau bertukar jadwal kerja dengan teman yang bekerja di Puskesmas atau rumah sakit, sedangkan solusi lain yang dilakukan oleh individu dengan status jero dengan proses pemilihan oleh prajuru adat adalah dengan penambahan anggota jero nyarikan baru, maka dengan penambahan anggota, kewajiban dan tugas yang diemban dapat dibagi dan meringankan beban pada jero nyarikan. 


\section{N.L.M.R CEMPAKA DAN D.H TOBING}

Salah satu pemecahan masalah yang bisa dilakukan adalah dengan strategi coping. Coping adalah perilaku yang terlihat dan tersembunyi yang dilakukan seseorang untuk mengurangi atau menghilangkan ketegangan psikologi dalam kondisi yang penuh stres (Yani, 1997). Ada dua strategi coping menurut Lazarus dan Folkman (dalam Maryam, 2017) yaitu strategi coping berfokus pada masalah dan strategi coping berfokus pada emosi. Strategi coping berfokus pada masalah adalah suatu tindakan yang diarahkan kepada pemecahan masalah. Individu akan cenderung menggunakan perilaku ini bila dirinya menilai masalah yang dihadapinya masih dapat dikontrol dan dapat diselesaikan. Meminta bantuan kepada keluarga, teman, ataupun pada orang-orang sekitar merupakan salah satu strategi coping berfokus pada masalah. Sesuai dengan kedua responden pada penelitian ini yang meminta bantuan kepada keluarga dan orang-orang sekitar agar dapat menyelesaikan permasalahan konflik yang dialami responden.

Lazarus dan Folkman (dalam Maryam, 2017) menyebutkan bahwa strategi coping berfokus pada emosi adalah melakukan usaha-usaha yang bertujuan untuk memodifikasi fungsi emosi tanpa melakukan usaha mengubah stressor secara langsung. Perilaku coping yang berpusat pada emosi cenderung dilakukan bila individu merasa tidak dapat mengubah situasi yang menekan dan hanya dapat menerima situasi tersebut karena sumberdaya yang dimiliki tidak mampu mengatasi situasi tersebut pemecahan masalah yang dilakukan oleh kedua responden penelitian, hal ini juga sesuai dengan kedua responden yang hanya dapat menerima keadaan ketika tidak ada jalan keluar saat konflik antar peran yang terjadi yang mengakibatkan stres pada diri responden.

Secara keseluruhan hasil penelitian ini dapat disimpulkan bahwa individu dengan peran sebagai jero di Kabupaten Bangli mengalami konflik pada peran-peran yang dimiliki. Hal tersebut dikarenakan benturan antar peran yang terjadi terkait tugas dan tanggung jawab yang harus dilaksanakan individu dengan status jero di Kabupaten Bangli. Konflik yang terjadi pada individu dengan peran jero lebih pada konflik dalam diri yang terjadi pada kedua responden. Hal itu terjadi karena tidak dapat mengatur waktu, sehingga bentuk konflik pada kedua responden adalah konflik waktu. Akibat konflik waktu yang dialami oleh kedua responden muncul stres dan rasa bersalah yang berdampak pada lingkungan sekitar responden, seperti lingkungan keluarga dan lingkungan masyarakat. Semakin banyak peran yang dimiliki individu, maka semakin meningkat kemungkinan konflik yang akan terjadi. Dukungan orang-orang sekitar sangatlah penting dalam penyelesaian konflik pada individu yang menjalani peran sebagai jero dan menajalani peran-peran lainnya.

Saran praktis yang dapat diberikan bagi peneliti selanjutnya terkait dengan keterbatasan referensi adalah diharapkan dapat mengkaji lebih dalam mengenai konflik peran terutama konflik peran pada individu berstatus jero yang menjalani prosesi ngerawang di Kabupaten Bangli atau di daerah-daerah lain dan diharapkan dapat menambahkan sudut pandang yang baru, karena sudut pandang yang lebih luas terhadap penelitian dapat menjadikan penelitian lebih komprehensif dan terintegrasi.

\section{DAFTAR PUSTAKA}

Ardhana, K., Soenaryo, F., Suwitha, G., Putra, I.B., \& Sulandjari. (2011). Masyarakat multikultural Bali. Denpasar: Komunitas Bambu.

Bogdan, R. C., \& Biklen, S. K. (2007). Qualitative research for education: An introduction to theory and methods. New York: Pearson Education.

Bungin, B. (2007). Penelitian kualitatif: Komunikasi, ekonomi, kebijakan publik dan ilmu sosial lainnya. Jakarta: Putra Grafika.

Cempaka, N. L. (2017). Konflik peran pada jero yang menjalani prosesi ngerawang di Kabupaten Bangli. Studi kasus. Universitas Udayana.

Cresswell, J. W. (2009). Research design: Qualitative, and mixed methods approaches. Los Angeles: Sage Publications.

Dalu, K. B. (2011). Cara mudah memahami agama Hindu. Denpasar: CV. Kayumas Agung.

Defrain, J., \& Stinnett, N. (2003). Family strength: International encylopedia of marriage and family. New York: The Gale Group Inc.

Feist, J., \& Feist, G. J. (2010). Teori kepribadian: Theories of personality. Jakarta: Salemba Humanika.

Forsyth, P. (2009). Jangan sia-siakan waktumu: Ahli bahasa Rifky. Yogyakarta: PT Garailmu.

Gea, A. A. (2014). Time management: Menggunakan waktu secara efektif dan efisien. Jurnal Ilmiah Management. 5(2), 777785. Diakses dari http://researchdashboard.binus.ac.id/uploads/paper/document/publication/ Proceeding/Humaniora/Vol\%205\%20no\%202\%20Oktober $\% 202014 / 22$ CB_Antonius.pdf

Gunawan, I. (2016). Metode penelitian kualitatif: Teori \& praktek. Jakarta: Bumi Aksara.

Kartono, K. (1980). Pengantar metodologi research sosial. Bandung: Penerbit Alumni.

Kementrian Kesehatan Republik Indonesia [Kemenkes RI]. (2007). Standar profesi bidan nomor 369/MENKES/SK/III. Jakarta: Mentri Kesehatan Republik Indonesia.

Lazarus, R. S \& Folkman, S. (1984). Stress, appraisal, and coping. New York: McGraw-Hill, Inc.

Lestari, S. (2012). Psikologi Keluarga penanaman nilai dan penanganan konflik dalam keluarga. Jakarta: Kencana.

Macan, T. (2000). Time management: Test of process model. Journal of Applied Psychology. 79(3), 381-391. Diakses dari https://pdfs.semanticscholar.org/ed69/8d9e95d8725c8edc6a 922d152b77dc8e0276.pdf

Maryam, S. (2017). Strategi coping: Teori dalam sumberdaya alam. Jurnal konseling. 1(2), 101-107. Diakses dari file:///E:/jurnal_copping.pdf

Moleong, L. J. (2014). Metodologi penelitian kualitatif. Bandung: PT Remaja Rosdakarya.

Poerwadinata, J. S. (2009). Kamus umum bahasa Indonesia edisi ketiga. Jakarta: Balai Pustaka.

Riggio, R. E. (2009). Introduction to industrial/ organization psychology. New Jersey: Pearson Education.

Robbins, S. P. (2001). Perilaku organisasi: Konsep kontroversi, aplikasi. Jakarta: Prenhallindo.

Setyadin, B. (2005). Desain dan metode penelitian kualitatif. Kota Baru, Kalimantan Selatan.

Singh, D., \& Jain, S.J. (2013). Working process of time management in SAR HP module. International Journal of Management Research and Review. 2(4), 2249-8954, Diakses dari https://www.ijeat.org/wp- 
content/uploads/Abstarct_Book_IJEAT_v2i4_Apri1\%2030_ \%202013.pdf

Strauss, A., \& Corbin, J. (2013). Dasar-dasar penelitian kualitatif. Yogyakarta: Pustaka Pelajar.

Sudharta, T. K., Purwita, I.B., Krisnu, T.R., Sura, I.G., Arwati, N.M., \& Wiana, I.K. (1991). Indik kepemangkuan. Denpasar: CV. Kayumas Agung.

Sugiarta,O., \& Adnyana, B. (2013). Agem-agem pemangku. Gianyar: Gandapura.

Swadiana, J. M. (2009). Pemangku juga manusia. Surabaya: Paramita.

Swastika, I.M., \& Pasek, I.K. (2009). Upacara mawinten. Denpasar: Kayumas Agung.
Vratasti, I. G., \& Wilani, N. M. (2016). Perbedaan subjective wellbeing pada perempuan yang menikah sesama wangsa dan berbeda wangsa. Jurnal Psikologi, 3(3), 2354-5607. Diakses dari

https://ojs.unud.ac.id/index.php/psikologi/article/view/2806 6

Weinberg, R., \& Gould, D. (2003). Foundations of sport and exercise psychology. USA: Human Kinetics.

Winardi, J. (2003). Entrepreneur \& entrepreneurship. Kencana Prenada Media Group. 


\section{LAMPIRAN}

Gambar 1

Pengalaman awal responden pertama GD

\begin{tabular}{|c|c|c|c|c|c|}
\hline $\begin{array}{c}\text { Pengaiamen } \\
\text { Awal }\end{array}$ & 마 & Menolak & $\Rightarrow$ & $\begin{array}{c}\text { Murcul } \\
\text { permasalahan }\end{array}$ & Menerima \\
\hline $\begin{array}{l}\text { Ditunjuk ol } \\
\text { pengurus de }\end{array}$ & & $\begin{array}{l}\text { Tidak } \\
\text { menja } \\
\text { peran } \\
\text { jero }\end{array}$ & $\begin{array}{l}\text { pan } \\
\text { kagai }\end{array}$ & $\begin{array}{l}\text { Anak Sakit } \\
\text { Pernasalahan } \\
\text { keiuzrga }\end{array}$ & $\begin{array}{l}\text { Masiziz } \\
\text { veratasi } \\
\text { Peran baru }\end{array}$ \\
\hline
\end{tabular}

Gambar 2

Konflik peran pada responden GD

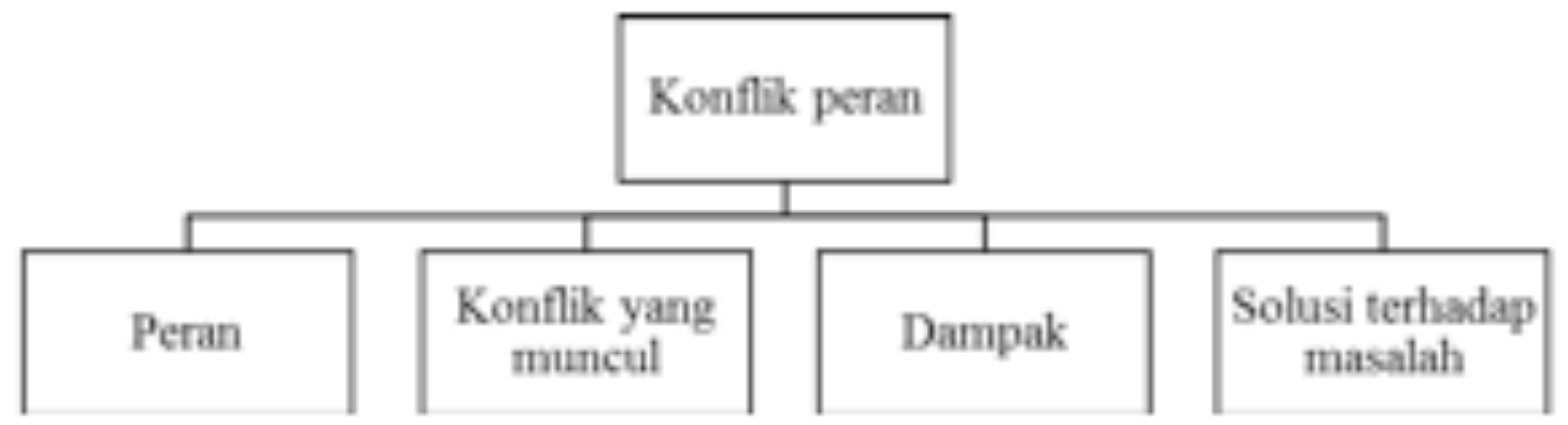

Gambar 3

Pengalaman awal responden AN

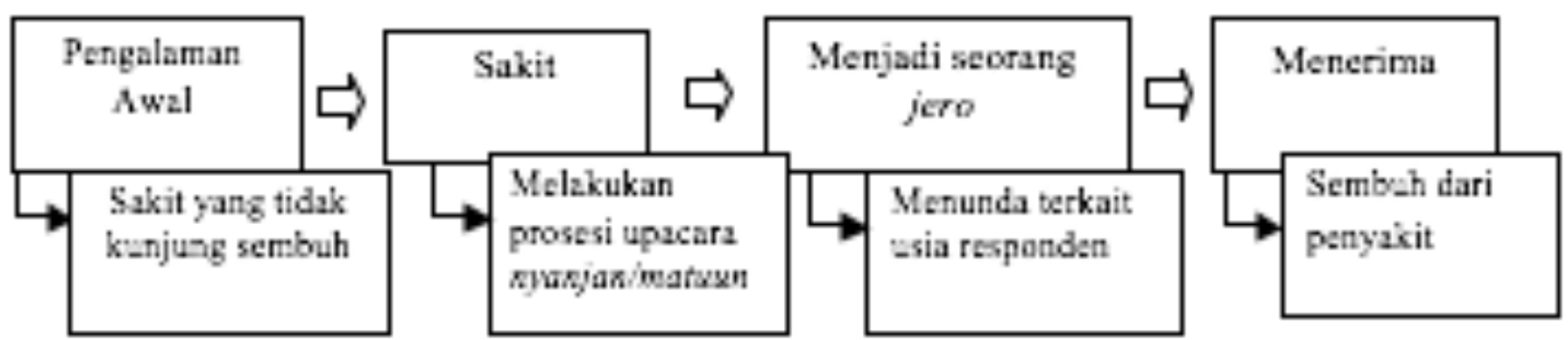


Gambar 4

Konflik peran pada responden AN

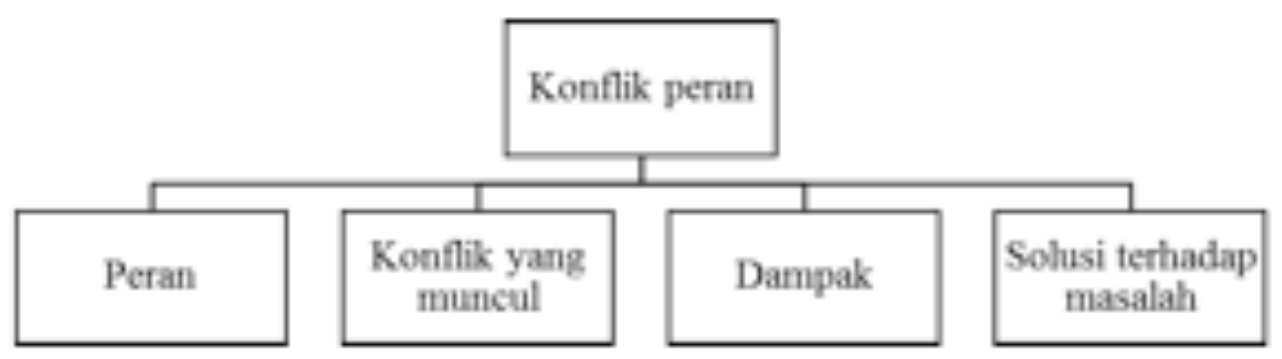

Table 1.

Perbandingan hasil konflik peran, dampak dan solusi penyelesaian masalah pada kedua kasus

\begin{tabular}{|c|c|c|c|}
\hline Tema & & $\begin{array}{c}\text { Kasus I } \\
\text { (Jero yang ditunjuk) }\end{array}$ & $\begin{array}{c}\text { Kasus II } \\
\text { (Jero yang melakukan } \\
\text { nyanjan/matyan) }\end{array}$ \\
\hline $\begin{array}{l}\text { Tema } \\
\text { pertama }\end{array}$ & Pengalaman $\Lambda w z$ & $\begin{array}{l}\text { a. Ditunjuk } \\
\text { b. Menjadi jero } \\
\text { setelah menikah } \\
\text { c. Menolak } \\
\text { d. Muncal masalah. } \\
\text { masalah } \\
\text { e. Menerima } \\
\text { f. Jero Nyarikan }\end{array}$ & $\begin{array}{l}\text { a. Szkit (nуanjan/matrun) } \\
\text { b. Menjadi Jero ketika } \\
\text { masih balita } \\
\text { c. Penundaan } \\
\text { d. Szkit yang tak kunjung } \\
\text { sembuh } \\
\text { e. Menerima } \\
\text { f. Jero Dasarzn }\end{array}$ \\
\hline \multirow[t]{4}{*}{$\begin{array}{l}\text { Tema } \\
\text { kedua }\end{array}$} & Peran & $\begin{array}{l}\text { a. Jero nyarikan } \\
\text { b. Guru } \\
\text { c. Wakil kepala } \\
\text { sekolah } \\
\text { d. Petani }\end{array}$ & $\begin{array}{l}\text { a. Jero dasaran } \\
\text { b. Bidan }\end{array}$ \\
\hline & Konflik yzng muncul & $\begin{array}{l}\text { a. Tuntutan peran } \\
\text { b. Permasalahan } \\
\text { keluarga } \\
\text { c. Permasalahan } \\
\text { dengan istri } \\
\text { d. Stres }\end{array}$ & $\begin{array}{l}\text { a. Benturan antar peran } \\
\text { b. Permasalahan } \\
\text { Peskesmas dan Klinik } \\
\text { c. Tuntutan orangtua } \\
\text { d. Perasazn tidak enak dan } \\
\text { rasa bersalah }\end{array}$ \\
\hline & Dampak & $\begin{array}{l}\text { a. Anak terabzikan } \\
\text { b. Orang tua banyak } \\
\text { mengambil alih } \\
\text { pengasuhan anak } \\
\text { c. Istri sering } \\
\text { menggantikan } \\
\text { peran suami } \\
\text { d. Masyarakat } \\
\text { menunggu }\end{array}$ & $\begin{array}{l}\text { a. Teguran dari atasan } \\
\text { b. Teman komplain } \\
\text { c. Tidak memiliki waktu } \\
\text { dengan pacar } \\
\text { d. Pasien menunggu } \\
\text { e. Gaji di potong }\end{array}$ \\
\hline & $\begin{array}{l}\text { Solusi ierhadap } \\
\text { Masalah }\end{array}$ & $\begin{array}{l}\text { a. Time management } \\
\text { b. Peran digantikan } \\
\text { c. Memberi } \\
\text { Pengertian } \\
\text { d. Penambahan } \\
\text { anggota baru }\end{array}$ & $\begin{array}{l}\text { a. Time management } \\
\text { b. Peran yang digantikan } \\
\text { c. Bantuan otangtua }\end{array}$ \\
\hline
\end{tabular}


Table 2.

Perbandingan dinamika kategori pengalaman awal jero yang dipilih dan melakukan Nyanjan/Matuun

\begin{tabular}{|c|c|c|}
\hline Dinamika & $\begin{array}{l}\text { Jero dengan proses } \\
\text { dipilih }\end{array}$ & $\begin{array}{l}\text { Jero yang melakukan } \\
\text { nyanjan/matumn }\end{array}$ \\
\hline Penyebab awal & $\begin{array}{l}\text { Dipilih oleh prajwer adat } \\
\text { dan keluarga besar }\end{array}$ & $\begin{array}{l}\text { Sakit yang tidak kunjung } \\
\text { sembuh }\end{array}$ \\
\hline Status & Menikah & $\begin{array}{l}\text { Belum menikah (saat masih } \\
\text { balita) }\end{array}$ \\
\hline Reaksi awal & Menolak & $\begin{array}{l}\text { Keluarga Menunda karena } \\
\text { masih balita }\end{array}$ \\
\hline $\begin{array}{l}\text { Dampak } \\
\text { penolakan/penundaan }\end{array}$ & Permasalahan keluarga & $\begin{array}{l}\text { Sakit yang tidak kunjung } \\
\text { sembuh }\end{array}$ \\
\hline Keputusan akhir & Menerima & Menerima \\
\hline
\end{tabular}

Table 3.

Perbandingan dinamika kategori konflik peran dan penyelesaian konflik antara jero yang dipilih dengan jero yang melaksanakan nyanjan/matuun

\begin{tabular}{|c|c|c|}
\hline Dinamika & Jero dengan proses dipilih & $\begin{array}{l}\text { Jero yang melakukan } \\
\text { nyanjan/matuan }\end{array}$ \\
\hline Peran & $\begin{array}{ll}\text { 1. } & \text { Jero Nyarikan } \\
\text { 2. } & \text { Guru } \\
\text { 3. } & \text { Petani }\end{array}$ & $\begin{array}{ll}\text { 1. } & \text { Jewo } \\
\text { 2. } & \text { Bidan }\end{array}$ \\
\hline Konflik yang muncul & $\begin{array}{l}\text { 1. Eksternal, tuntutan } \\
\text { keluarga dan tuntutan } \\
\text { peran } \\
\text { 2. Internal, stres terhadap } \\
\text { tuntutan peran }\end{array}$ & $\begin{array}{l}\text { 1. Eksternal, tuntutan } \\
\text { peran } \\
\text { 2. Internal, rasa bersalah }\end{array}$ \\
\hline Dampak & $\begin{array}{l}\text { 1. Pengabaian terhadap } \\
\text { kewajiban pada } \\
\text { lingkungan keluarga dan } \\
\text { pekerjaan } \\
\text { 2. Hasil pekerjaan yang } \\
\text { kurang maksimal }\end{array}$ & $\begin{array}{l}\text { 1. Teguran dari atasan } \\
\text { 2. Gaji dipotong } \\
\text { 3. Pasien tidak ditangani } \\
\text { dengan baik }\end{array}$ \\
\hline $\begin{array}{l}\text { Solusi } \\
\text { masalah }\end{array}$ & $\begin{array}{l}\text { 1. Time management } \\
\text { 2. Penambahan anggota } \\
\text { baru } \\
\text { 3. Strategi coping }\end{array}$ & $\begin{array}{l}\text { 1. Time Management } \\
\text { 2. Peran yang digantikan } \\
\text { 3. Strategi coping }\end{array}$ \\
\hline
\end{tabular}

